\section{Fruit Composition and Sensory Attributes of Organic Heirloom Tomatoes as Affected by Grafting}

\author{
Charles E. Barrett ${ }^{1}$, Xin Zhao ${ }^{1,4}$, Charles A. Sims ${ }^{2}$, \\ Jeffrey K. Brecht ${ }^{1}$, Eric Q. Dreyer ${ }^{2}$, and Zhifeng $\mathrm{GaO}^{3}$
}

ADDITIONAL INDEX WORDs. consumer preference, rootstock, soluble solids, Solanum lycopersicum, S. lycopersicum $\times S$. habrochaites, vitamin C

SUMMARY. Grafting has many purposes in vegetable production. It is used for control of soilborne pathogens, season extension in protected culture, and improving productivity in cucurbitaceous and solanaceous crops. Consumers desire heirloom tomatoes (Solanum lycopersicum) for their perceived excellent flavor. Heirloom tomatoes are susceptible to many soilborne diseases and may benefit from grafting onto more robust, disease-resistant rootstocks especially under organic production. In this two-year study, heirloom tomato 'Brandywine' was grafted onto tomato hybrid 'Survivor' and interspecific tomato hybrid 'Multifort' rootstocks to determine the effects of grafting on fruit quality attributes such as soluble solids content (SSC), pH, total titratable acidity (TTA), and vitamin C. Nongrafted and self-grafted 'Brandywine' tomatoes were included as controls. Consumer sensory tests were also conducted to assess the effects of grafting on overall appearance and acceptability, firmness, tomato flavor, and sweetness. No significant differences in vitamin $\mathrm{C}$, SSC, pH, or TTA were found in fruit from the nongrafted, self-grafted, and 'Brandywine' grafted with the two rootstocks either year. The SSC of all tomatoes in 2010 was lower than that of 2011 . In 2010 , fruit from 'Brandywine' grafted onto the rootstock 'Survivor' was scored significantly lower in appearance, acceptability, and flavor than the nongrafted 'Brandywine' treatment. All grafted treatments resulted in a significant decrease in acceptability ratings in the consumer sensory test. No significant differences were observed between nongrafted and grafted treatments in 2011. Consumers who reported more frequent consumption of fresh tomato tended to give lower ratings for most sensory attributes evaluated. Harvest time and fruit ripeness need to be considered in future research to better understand the influence of grafting with selected rootstocks on fruit composition and sensory attributes of heirloom tomatoes.

$\mathrm{G}$ rafting is a horticultural technique primarily used to control soilborne pathogens, reduce abiotic stresses, and improve crop productivity in cucurbitaceous and solanaceous vegetables (Kubota et al., 2008; Lee et al., 2010). This technique may be especially useful as a management tool for soilborne diseases in organic production. Several recent studies have demonstrated the effectiveness of grafting for controlling root-knot nematodes (Meloidogyne sp.), bacterial wilt (caused by Ralstonia solanacearum),

This project was supported by a Southern Region Sustainable Agriculture Research and Education (SARE) Graduate Student Grant (GS10-096).

Thanks to Takii Seeds USA for providing 'Survivor' rootstock seeds and De Ruiter Seeds Inc. for providing 'Multifort' seeds.

${ }^{1}$ Horticultural Sciences Department, University of Florida, Gainesville, FL 32611

${ }^{2}$ Food Science and Human Nutrition Department, University of Florida, Gainesville, FL 32611

${ }^{3}$ Food and Resource Economics Department, University of Florida, Gainesville, FL 32611

${ }^{4}$ Corresponding author. E-mail: zxin@ufl.edu. fusarium wilt (caused by Fusarium oxysporum), and southern blight (caused by Sclerotium rolfsii) in the United States (Bausher, 2009; Kubota et al., 2008; López-Pérez et al., 2006; Rivard and Louws, 2008; Rivard et al., 2010a). Grafting research and breeding efforts for both tomatoes and tomato rootstocks have traditionally focused on increasing yield, improving disease resistances, and extending postharvest shelf life (King et al., 2010; Klee, 2010; Rouphael et al., 2010). Consumers are not satisfied with fruit and vegetable flavors and are willing to pay a premium price for produce with improved taste (Klee, 2010). With this increase in consumer interest in fruits and vegetables with superior flavor, more recent studies have examined grafting effects on fruit quality (Di Gioia et al., 2010; Fernández-Garcia et al., 2004; Mišković et al., 2009; Pogonyi et al., 2005).

Results on fruit quality from grafted tomato plants have been mixed (Edelstein, 2004; Martínez-Ballesta et al., 2008; Rouphael et al., 2010). Increased concentrations of lycopene, $\beta$-carotene, and SSC in tomato fruit as a result of grafting with selected rootstocks have been reported (FernándezGarcia et al., 2004; Flores et al., 2010). On the other hand, reduced levels of SSC, total sugars, vitamin C, and total phenolics were found in fruit from tomato plants grafted onto certain rootstocks as compared with nongrafted plants (Di Gioia et al., 2010; Pogonyi et al., 2005; Turhan et al., 2011; Vinkovic Vrcek et al., 2011). Furthermore, some reports showed no significant differences in $\mathrm{pH}$, TTA, SSC, and lycopene content in fruit from grafted vs. nongrafted plants (Khah et al., 2006; Romano and Paratore, 2001). To date, few studies have examined the effect of grafting on fruit quality and sensory attributes of heirloom tomatoes, which are often perceived to have outstanding eating quality (Di Gioia et al., 2010). Increased yields and enhanced fruit quality attributes are essential for growers to justify the higher cost of grafted tomato plants. This cost, as reported by Rivard et al. (2010b), could be $147 \%$ to $354 \%$ higher for grafted plants produced in the United States.

Grafting may provide an effective management tool for tomato growers to control soilborne pathogens and reduce environmental stresses. However, if fruit quality is adversely affected as a result of grafting, growers may be less likely to adopt this technique. Tomato hybrid and interspecific tomato hybrid rootstocks are the two major types of commercially

\begin{tabular}{llll}
\hline $\begin{array}{l}\text { Units } \\
\text { To convert U.S. to SI, } \\
\text { multiply by }\end{array}$ & U.S. unit & SI unit & $\begin{array}{l}\text { To convert SI to U.S., } \\
\text { multiply by }\end{array}$ \\
\hline 29.5735 & $\mathrm{fl} \mathrm{oz}$ & $\mathrm{mL}$ & 0.0338 \\
2.54 & inch $(\mathrm{es})$ & $\mathrm{cm}$ & 0.3937 \\
25.4 & inch $(\mathrm{es})$ & $\mathrm{mm}$ & 0.0394 \\
1.1209 & $\mathrm{lb} / \mathrm{acre}$ & $\mathrm{kg} \cdot \mathrm{ha}^{-1}$ & 0.8922 \\
0.1 & $\mathrm{ppm}$ & $\mathrm{mg} / 100 \mathrm{~g}$ & 10 \\
$\left({ }^{\circ} \mathrm{F}-32\right) \div 1.8$ & ${ }^{\circ} \mathrm{F}$ & ${ }^{\circ} \mathrm{C}$ & $\left({ }^{\circ} \mathrm{C} \times 1.8\right)+32$
\end{tabular}


available tomato rootstocks. The objective of this study was to examine the impact of grafting with the two types of rootstocks on fruit composition and sensory attributes of organically grown heirloom tomatoes.

\section{Materials and methods}

Grafted transplants. Heirloom tomato cultivar Brandywine $[\mathrm{BW}$ (TomatoFest, Little River, CA)] was used as scion with 'Multifort' [MU (De Ruiter Seeds, Bergschenhoek, The Netherlands)] and 'Survivor' [SU (Takii Seeds, Salinas, CA)] as rootstocks. 'Brandywine' is a red colored, beefsteak type, open pollinated, indeterminate heirloom cultivar known for outstanding flavor. 'Multifort' is an interspecific tomato ( $S$. lycopersicum $\times$ $S$. habrochaites) hybrid rootstock, whereas 'Survivor' is a regular tomato (S. lycopersicum) hybrid rootstock. Both are vigorous rootstocks with resistance to several soilborne pathogens and root-knot nematodes. Certified organic heirloom tomato scion seeds and untreated rootstock seeds were used. The rootstock seeds were sown on 16 Feb. 2010 and 11 Feb. 2011, $2 \mathrm{~d}$ before scion seeds, as recommended by both rootstock seed companies.

Flats (128-cell; Speedling, Sun City, FL) and commercial potting mix (Organic Formula Custom; Fafard, Apopka, FL) were used to grow the seedlings. Seedlings were tube grafted at the four to five true-leaf stage. Grafting took place $34 \mathrm{~d}$ (2010) and $28 \mathrm{~d}$ (2011) after scions were sown. The grafting and healing protocol was adapted from Rivard and Louws (2008). The newly grafted seedlings were held together with 1.5- or 2.0-mm silicone clips (Hydro-Gardens, CO Springs, CO). After grafting, the seedlings were placed in a climatecontrolled walk-in cooler at $25^{\circ} \mathrm{C}$ and $\approx 95 \%$ relative humidity without light for $24 \mathrm{~h}$. The seedlings were progressively exposed to increased light durations and reduced humidity for $6 \mathrm{~d}$, until the graft unions had healed. Healed grafted seedlings were relocated to a greenhouse to harden off for $5 \mathrm{~d}$ before transplanting.

Field EXPERIMENTS. Tomato seedlings were transplanted on $10 \mathrm{Apr}$. 2010 and 2 Apr. 2011. Both field experiments were arranged in a randomized complete block design with five blocks. There were 12 and 15 plants per plot in 2010 and 2011, respectively. Both trials consisted of four treatments: nongrafted (NGBW) and self-grafted (BW/BW) 'Brandywine', and 'Brandywine' grafted onto 'Multifort' (BW/MU) or 'Survivor' $(\mathrm{BW} / \mathrm{SU})$. The plants were grown on raised beds with black plastic mulch and drip irrigation. Granular fertilizer (10N-0.9P-6.6K; Nature Safe, Cold Spring, KY) was applied preplant at a rate of $200 \mathrm{lb} /$ acre nitrogen. Fishand seaweed-based liquid fertilizer (2N-1.3P-0.8K; Neptune's Harvest, Gloucester, MA) was injected into the drip system weekly at a rate of $1.7 \mathrm{lb} /$ acre nitrogen throughout the season to provide supplemental fertilization. The stake and weave system common to Florida fresh market tomato production was used and plants were trellised to provide vertical support (Olson et al., 2011).

Both field trials took place at the University of Florida Plant Science Research and Education Unit in Citra. Tomato plants were grown on certified organic land in compliance with the National Organic Program (U.S. Department of Agriculture, 2002).

FRUIT COMPOSITION ANALYSES. Vitamin C, SSC, pH, and TTA were determined for tomato fruit from all four treatments harvested on 13 June 2010 and 8 June 2011 . At the second harvest in both years, five representative fruit were picked at the breaker stage, which ensured that the fruit samples were at a uniform developmental stage. The harvested fruit were allowed to ripen at ambient storage temperature $\left(\approx 75^{\circ} \mathrm{F}\right)$ for $3-4 \mathrm{~d}$ before being cut into pieces and blended for $30 \mathrm{~s}$ to form a homogenate for each treatment. Three replicates of the composite sample of each treatment were analyzed in both years. The homogenate was centrifuged for $20 \mathrm{~min}$ at $17,600 g_{n}$ and $5^{\circ} \mathrm{C}$. Then the resulting supernatant was filtered through eight layers of cheesecloth to obtain a clarified extract. Vitamin C was measured using a microplate spectrophotometer (PowerWave XS2; BioTek, Winooski, VT) with absorbance at 540 nm (Terada et al., 1978). Percent SSC was measured with a digital refractometer (Abbe Mark II; Reichert Technologies, Depew, NY). Initial pH was recorded, and TTA in terms of percent citric acid milliequivalents was determined by potentiometric titration of $6 \mathrm{~mL}$ of tomato extract to an endpoint of $\mathrm{pH}=8.2$ with $0.1 \mathrm{~N}$ sodium hydroxide using an automatic titrator (719 S Titrino; Metrohm, Herisau, Switzerland).

CONSUMER SENSORY ANALYSES. Consumer sensory tests were conducted in 2010 and 2011 at the University of Florida Sensory Analysis Laboratory in Gainesville. Fruit were harvested at the breaker stage of development and allowed to ripen to full color before analysis. In the 2010 study, tomato fruit from NGBW, $\mathrm{BW} / \mathrm{BW}, \mathrm{BW} / \mathrm{MU}$, and $\mathrm{BW} / \mathrm{SU}$ were harvested on 13 June and stored at ambient temperature $\left(\approx 75^{\circ} \mathrm{F}\right)$ for $3 \mathrm{~d}$ before the sensory evaluation. In 2011, tomatoes from NGBW, BW/BW, $\mathrm{BW} / \mathrm{MU}$, and $\mathrm{BW} / \mathrm{SU}$ were harvested on 13 June and assessed after $4 \mathrm{~d}$ at the same ambient temperature. Fruit from the five field blocks were pooled for each treatment to provide enough ripe fruit for $>100$ sensory analysis samples. Tomatoes were cut from stem end to blossom end into wedges $\approx 1$ inch thick. Each serving sample consisted of two wedges of tomato fruit. There were 75 and 69 consumer panelists for the 2010 and 2011 sensory tests, respectively. Sensory test data were collected and analyzed using Compusense ${ }^{\circledR}$ Five (Compusense, Guelph, ON, Canada) software. All procedures used were approved by the University of Florida Institutional Review Board.

The sensory tests began with three demographic questions: gender, age, and frequency of fresh tomato consumption (Table 1). Each panelist was then asked to "indicate how much you like or dislike the following attributes" using a hedonic scale. The attributes assessed were overall appearance, overall acceptability, firmness, tomato flavor, and sweetness. The hedonic scale ranged from 1 to 9 ( 1 = dislike extremely, 2 = dislike very much, 3 = dislike moderately, $4=$ dislike slightly, $5=$ neither like nor dislike, $6=$ like slightly, 7 = like moderately, 8 = like very much, $9=$ like extremely). Panelists cleansed their palates between samples using cracker and water. After completing the taste test, each panelist was compensated for their participation.

The order in which the tomato samples were presented to each panelist was randomized to reduce bias caused by the order in which the samples were presented. All possible orders were presented about an equal number 
Table 1. Demographic information about consumers participating in sensory analyses of grafted heirloom tomato 'Brandywine' in 2010 and 2011.

\begin{tabular}{llcc}
\hline Characteristic & \multicolumn{1}{c}{ Category } & $\begin{array}{c}\mathbf{2 0 1 0} \\
\text { Consumers }^{\mathbf{z}} \text { (\%) }\end{array}$ & $\begin{array}{c}\mathbf{2 0 1 1} \\
\text { Consumers }^{\mathbf{z}} \text { (\%) }\end{array}$ \\
\hline Gender & Male & 51 & 54 \\
Age (years) & Female & 49 & 46 \\
& Under 18 & 0 & 3 \\
& $18-29$ & 80 & 74 \\
& $30-44$ & 15 & 14 \\
Fresh tomato & $45-65$ & 4 & 9 \\
consumption & Oore than once per week & 1 & 0 \\
frequency & Once per week & 52 & 49 \\
& More than once per mo. & 26 & 20 \\
& Once per mo. & 17 & 16 \\
& Never & 5 & 10 \\
\hline
\end{tabular}

${ }^{2} 75$ consumers participated in 2010; 69 consumers participated in 2011 .

of times. Following each sensory panel, the data were collected from all computers and compiled.

STATISTICAL ANALYSES. Data were analyzed using SAS (version 9.2 for Windows; SAS Institute, Cary, NC). Fruit composition data were analyzed using a one-way analysis of variance (ANOVA) with Tukey's honestly significant difference (HSD) test $(P \leq$ 0.05 ) for multiple comparisons among treatments. The consumer sensory test data were collected and analyzed using a one-way ANOVA with Tukey's HSD test $(P \leq 0.05)$ for multiple comparisons among treatments. To determine the impact of demographics on consumer sensory scores, regression analysis was conducted. In the regression, sensory scores of appearance, acceptability, firmness, sweetness, and tomato flavor were specified as functions of demographic information (i.e., gender, age, or fresh tomato consumption frequency) and production methods (i.e., nongrafted or grafted). Interactions between production methods and demographics were also added to test whether interaction effects existed. However, statistical tests indicated that there were no significant interactions between demographics and production methods with respect to their influence on consumer ratings. Therefore, sensory scores were specified as linear functions of demographic information and production methods such as

$$
\begin{aligned}
\text { Sens_Score }= & \beta_{0}+\beta_{1} \cdot \text { Male }+\beta_{2} \cdot \text { Age } \\
& +\beta_{3} \cdot \text { Freq }+\beta_{4} \cdot \text { Graft } 1 \\
& +\beta_{5} \cdot \text { Graft } 2+\beta_{6} \cdot \text { Graft3 }
\end{aligned}
$$

where Sens_Score was consumer sensory ratings, Male was a dummy variable indicating whether a respondent was male or female, Age was a respondent's age, Freq was a respondent's frequency of fresh tomato consumption, and Graft1, Graft2, and Graft3 were dummy variables indicating the grafting treatments, i.e., self-grafting and grafting onto 'Multifort' and 'Survivor', respectively.

\section{Results and discussion}

FRUIT COMPOSITION MEASUREMENTS. No significant differences in vitamin C, SSC, pH, TTA, and SSC: TTA ratio between treatments were found in either year for 'Brandywine' fruit (Table 2). Few consistent effects of grafting or rootstock on quality attributes of tomatoes have been reported from previous studies. Khah et al. (2006) demonstrated that $\mathrm{pH}$, Brix, lycopene content, and firmness were unaffected when the commercial tomato cultivar Big Red was grafted onto 'Primavera' or 'Heman' tomato rootstocks. Similarly, Di Gioia et al. (2010) showed that SSC, TTA, and SSC:TTA ratio were not significantly influenced by grafting heirloom tomatoes onto interspecific hybrid rootstocks. Although vitamin $\mathrm{C}$ concentrations did not differ significantly between grafted and nongrafted tomato fruit in this study, decrease of fruit vitamin C levels as a result of grafting with selected tomato rootstocks has been observed by others (Di Gioia et al., 2010; Turhan et al., 2011; Vinkovic Vrcek et al., 2011). Other studies have also indicated that grafting could negatively affect nutritional quality of tomato fruit including the antioxidant properties (Davis et al., 2008; Edelstein, 2004; Vinkovic Vrcek et al., 2011).
In contrast, some previous research has shown that grafting with certain rootstocks may have a positive impact on tomato fruit quality by increasing carotenoid content (FernándezGarcia et al., 2004).

Rouphael et al. (2010) pointed out that grafted fruit quality attributes may be dependent on the selection of scions and rootstocks as well as growing environment. Tomato scion and rootstock combinations have even been reported to perform differently in consecutive years (Mišković et al., 2009). There are many possible scionrootstock combinations and growing environments. Clearly, more of these scenarios will need to be examined before researchers fully understand the impact of grafting with different rootstocks on fruit quality attributes. These studies will need to assess specific rootstocks for specific growing conditions in a variety of regions.

Environmental conditions may influence fruit quality more than the impact of grafting with rootstocks. It was demonstrated that SSC and TTA of tomato fruit varied significantly with harvest date despite the similar levels between grafted and nongrafted tomatoes (Di Gioia et al., 2010). Our results showed that SSC values in 2010 were lower than that measured in 2011 by $\approx 36.6 \%$ on average, whereas the average SSC:TTA ratio in 2010 was $\approx 43.2 \%$ lower than that in 2011. The vitamin $\mathrm{C}$ level in the 2010 fruit samples was also lower than the 2011 study by $17.6 \%$. Given the considerable seasonal variability and even the changes of fruit composition during the harvest season, multiple samplings are suggested when examining the influence of grafting on fruit composition and quality. Moreover, fruit ripening needs to be well considered in a grafted tomato study as SSC and carotenoid level often increases in tomato fruit with advancement of ripening stages (Raffo et al., 2002).

CONSUMER SENSORY ANALYSES. In the 2010 study, the consumers perceived some differences between 'Brandywine' fruit harvested from the nongrafted and grafted treatments in the sensory attributes evaluated (Table 3 ). There were significant differences regarding overall appearance, overall acceptability, and tomato flavor. For the overall appearance, fruit from nongrafted 'Brandywine' were 
rated significantly higher than fruit from 'Brandywine' grafted onto 'Survivor' rootstock. Grafting onto either 'Multifort' or 'Survivor' rootstocks resulted in a significant decrease in the overall acceptability rating compared with nongrafted tomatoes. The self-grafted scion control was included to differentiate the impact of the grafting process per se from the rootstock effect. Interestingly, fruit from self-grafted 'Brandywine' also showed significantly lower ratings of overall acceptability in contrast to the nongrafted tomatoes. Regardless of these differences detected, consumer ratings of tomato firmness and sweetness did not differ significantly between nongrafted and grafted treatments. Although grafting with the two rootstocks had a consistent negative effect on heirloom tomato flavor in the 2010 study, this trend did not persist in 2011. No significant differences were observed between nongrafted and grafted treatments for the measured sensory analysis attributes in the 2011 consumer sensory test. The 2011 season was generally drier and warmer with lower foliar disease incidence than the 2010 season. Crop vigor and tomato yields were higher in 2011 than in 2010 (Barrett et al., 2012). The grafting effect on tomato

Table 2. Vitamin C, soluble solids content (SSC), $\mathrm{pH}$, total titratable acidity (TTA), and SSC:TTA of nongrafted and self-grafted heirloom tomato 'Brandywine' and grafted 'Brandywine' with 'Multifort' and 'Survivor' rootstocks in 2010 and 2011.

\begin{tabular}{|c|c|c|c|c|c|}
\hline Treatment $^{\mathrm{z}}$ & $\begin{array}{l}\text { Vitamin } C^{y} \\
(\mathrm{mg} / 100 \mathrm{~g} \\
\text { fresh wt) }\end{array}$ & SSC (\%) & $\mathrm{pH}$ & $\begin{array}{c}\text { TTA } \\
(\% \text { citric acid })\end{array}$ & $\begin{array}{l}\text { SSC:TTA } \\
\text { (ratio) }\end{array}$ \\
\hline \multicolumn{6}{|c|}{2010} \\
\hline Nongrafted 'Brandywine' & 26.78 & 3.47 & 4.33 & 0.32 & 11.1 \\
\hline Self-grafted 'Brandywine' & 25.27 & 3.20 & 4.29 & 0.38 & 8.5 \\
\hline 'Brandywine' /'Multifort' & 24.85 & 2.40 & 4.31 & 0.34 & 8.0 \\
\hline 'Brandywine' / 'Survivor' & 25.75 & 3.37 & 4.26 & 0.43 & 8.4 \\
\hline$P$ value & 0.19 & 0.10 & 0.22 & 0.60 & 0.61 \\
\hline \multicolumn{6}{|c|}{2011} \\
\hline Nongrafted 'Brandywine' & 32.33 & 4.93 & 4.45 & 0.32 & 15.7 \\
\hline Self-grafted 'Brandywine' & 31.47 & 4.93 & 4.47 & 0.33 & 15.0 \\
\hline 'Brandywine' /'Multifort' & 30.79 & 4.97 & 4.44 & 0.31 & 16.2 \\
\hline 'Brandywine' /'Survivor' & 30.06 & 4.80 & 4.47 & 0.29 & 16.5 \\
\hline$P$ value & 0.33 & 0.45 & 0.74 & 0.13 & 0.30 \\
\hline
\end{tabular}

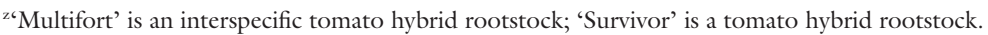

'Vitamin C content reported as milligrams of ascorbic acid per $100 \mathrm{~g}$ fresh weight; $1 \mathrm{mg} / 100 \mathrm{~g}=10 \mathrm{ppm}$. sensory attributes in response to variations in seasonal environmental conditions may deserve further studies. According to Di Gioia et al. (2010), grafting did not influence the sensory attributes "sweetness," "sourness," and "tomato-like taste" for the heirloom tomato cultivar Cuore di Bue. In their study, 'Cuore di Bue' was grafted onto the interspecific hybrid rootstock cultivars Beaufort and Maxifort, which were produced from the same breeding program as the rootstock 'Multifort' used in this study.

The regression analysis revealed similar results as the ANOVA regarding the grafting effects on consumer sensory ratings, with the exception that grafting with both rootstocks caused a significant decrease in tomato flavor rating in 2010 (Table 4). Gender and age did not have any significant impact on consumer sensory evaluation results. However, frequency of fresh tomato consumption showed significant influence on consumer sensory ratings for almost all the attributes evaluated in 2010 and 2011 except for the overall appearance evaluated in 2010. Interestingly, panelists with frequent tomato consumption were more likely to give lower scores in the sensory tests for either grafted or nongrafted tomatoes.

Tomato flavor is a complex balance of sugar and acid contents with aroma volatiles (Krumbein and Auerswald, 1998). Cultural practices and environmental conditions during fruit development can affect the ratios of flavor compounds in the fruit. Harvest

Table 3. Fruit sensory attribute ratings ${ }^{\mathrm{z}}$ of nongrafted and self-grafted heirloom tomato 'Brandywine' and grafted 'Brandywine' with 'Multifort' and 'Survivor' rootstocks in 2010 and 2011.

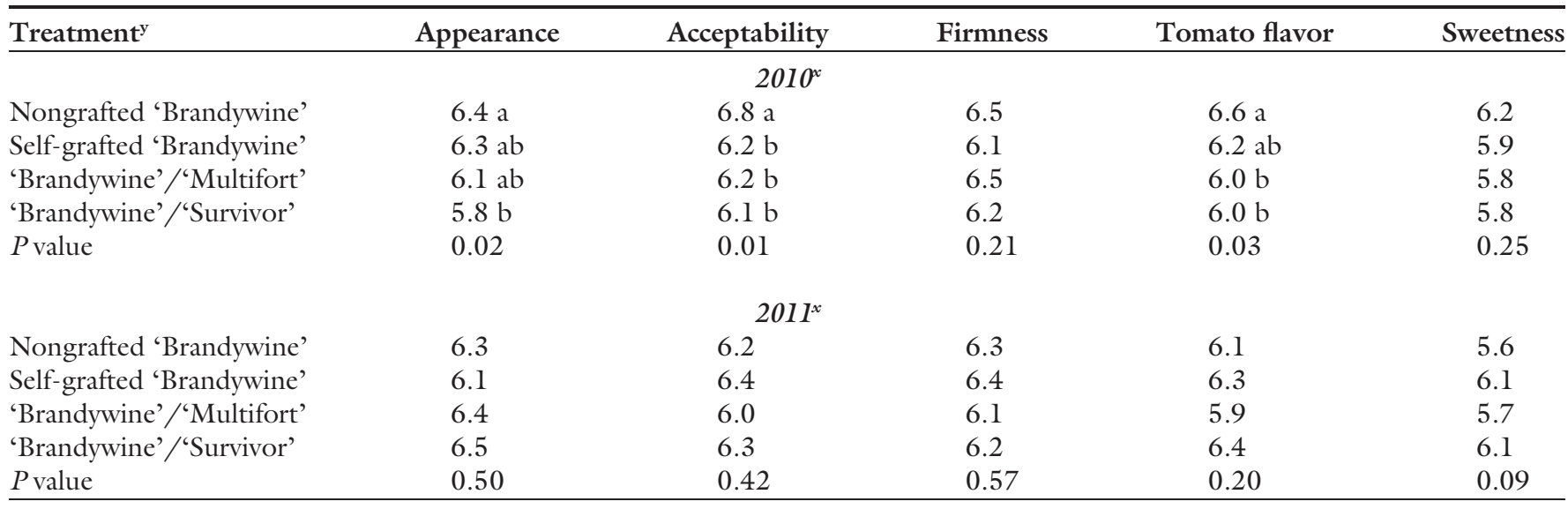

${ }^{\mathrm{z}}$ Sensory attribute ratings from consumer sensory tests using a nine-point hedonic scale $(1=$ dislike extremely, $9=$ like extremely); different letters within a column indicate significant differences at $P \leq 0.05$ by Tukey's honestly significant difference test.

'Multifort' is an interspecific tomato hybrid rootstock; 'Survivor' is a tomato hybrid rootstock.

${ }^{\times} 75$ consumers participated in 2010; 69 consumers participated in 2011 . 
Table 4. Regression analysis of effects of consumer demographics and grafting treatments on sensory attributes of heirloom tomato 'Brandywine' in 2010 and 2011.

\begin{tabular}{|c|c|c|c|c|c|c|c|c|c|c|}
\hline Variable $^{\mathrm{z}}$ & Appearance & $P$ & Acceptability & $P$ & Firmness & $P$ & Flavor & $P$ & Sweetness & $P$ \\
\hline \multicolumn{11}{|c|}{$2010^{y}$} \\
\hline Intercept & 6.74 & $<0.0001$ & 7.36 & $<0.0001$ & 6.95 & $<0.0001$ & 7.31 & $<0.0001$ & 6.65 & $<0.0001$ \\
\hline Male & 0.13 & 0.53 & 0.19 & 0.31 & 0.17 & 0.40 & 0.21 & 0.33 & 0.28 & 0.17 \\
\hline Age & -0.05 & 0.78 & -0.11 & 0.48 & -0.07 & 0.69 & -0.18 & 0.31 & 0.05 & 0.78 \\
\hline Frequency ${ }^{\mathrm{x}}$ & -0.18 & 0.10 & -0.26 & 0.01 & -0.24 & 0.02 & -0.22 & 0.05 & -0.40 & $<0.0001$ \\
\hline $\mathrm{BW} / \mathrm{BW}$ & -0.33 & 0.22 & -0.53 & 0.03 & -0.40 & 0.15 & -0.39 & 0.18 & -0.28 & 0.31 \\
\hline$R^{2}$ & 0.01 & & 0.05 & & 0.03 & & 0.04 & & 0.06 & \\
\hline \multicolumn{11}{|c|}{$2011^{y}$} \\
\hline Intercept & 7.20 & $<0.0001$ & 6.72 & $<0.0001$ & 6.53 & $<0.0001$ & 7.22 & $<0.0001$ & 7.20 & $<0.0001$ \\
\hline Male & 0.00 & 0.99 & -0.07 & 0.71 & -0.08 & 0.71 & -0.10 & 0.62 & 0.00 & 0.99 \\
\hline Age & -0.13 & 0.42 & 0.12 & 0.33 & 0.16 & 0.26 & 0.03 & 0.79 & -0.13 & 0.42 \\
\hline $\mathrm{BW} / \mathrm{SU}$ & 0.17 & 0.53 & 0.13 & 0.62 & -0.09 & 0.75 & 0.25 & 0.37 & 0.51 & 0.07 \\
\hline$R^{2}$ & 0.05 & & 0.11 & & 0.07 & & 0.17 & & 0.05 & \\
\hline
\end{tabular}

${ }^{2} \mathrm{BW} / \mathrm{BW}=$ self-grafted 'Brandywine'; $\mathrm{BW} / \mathrm{MU}=$ 'Brandywine' grafted onto the interspecific tomato hybrid rootstock 'Multifort'; BW/SU = 'Brandywine' grafted onto the tomato hybrid rootstock 'Survivor'.

y75 consumers participated in 2010;69 consumers participated in 2011 .

${ }^{x}$ Frequency of fresh tomato consumption.

maturity also has a major influence on flavor in climacteric fruits like tomato (Mattheis and Fellman, 1999). When tomato fruit are picked before reaching full ripeness and ripened off the plant, they tend to have less "tomato-like" flavor intensity, are less sweet, and have more off-flavor than tomatoes ripened on the plant (Kader et al., 1977). In this study, environmental conditions were more favorable and yields were much greater in 2011 than in 2010 (Barrett et al., 2012). As a result, more fruit were available at similar stages of development for the fruit composition measurements and consumer sensory tests in 2011. The sensory differences among 'Brandywine' fruit in 2010 between nongrafted and grafted plants may reflect the more variable SSC and ripeness stages of fruit in 2010.

Grafting may also affect the maturation of tomato fruit. Grafted plants can have delayed early harvests compared with nongrafted plants because the grafting and healing processes may delay fruit development (Khah et al., 2006; Lee et al., 2010). Khah et al. (2006) showed that there were no significant differences in the number of flowers per tomato plant later in the growing season. In our studies, fruit from the second and third harvests were used to reduce the variability of fruit maturity between grafted and nongrafted treatments. Harvest time has been shown to markedly affect the consumer-perceived appearance of tomato fruit (Klein et al., 2010). It would be advisable to conduct consumer sensory tests using fruit from different harvests during the production season to fully elucidate the influence of grafting on tomato sensory attributes. The effects of grafting per se and the use of rootstocks on fruit ripening also deserve more in-depth studies.

Heirloom tomato fruit are desired for their exceptional flavors, colors, and unique shapes. Overall, neither grafting nor rootstock demonstrated any pronounced effect on fruit composition of organically grown 'Brandywine' tomato fruit measured in this two-year study. Inconsistent impacts of self-grafting and grafting with disease-resistant rootstocks on fruit sensory attributes were observed. Growers interested in using grafted plants need to be aware that scionrootstock interactions are still not fully understood. It is suggested that different grafting combinations be evaluated under site-specific conditions before incorporating this technique on a large production scale.

\section{Literature cited}

Barrett, C.E., X. Zhao, and R. McSorley. 2012. Grafting for root-knot nematode control and yield improvement in organic heirloom tomato production. HortScience 47:614-620.

Bausher, M.G. 2009. Commercial tomato rootstock performance when exposed to natural populations of root-knot nematodes in Florida. HortScience 44:1021 (abstr.).

Davis, A.R., P. Perkins-Veazie, R. Hassel, A. Levi, S.R. King, and X. Zhang. 2008. Grafting effects on vegetable quality. HortScience 43:1670-1672.

Di Gioia, F., F. Serio, D. Buttaro, O. Ayala, and P. Santamaria. 2010. Influence of rootstock on vegetative growth, fruit yield, and quality in 'Cuore di Bue', an heirloom tomato. J. Hort. Sci. Biotechnol. 85:477-482.

Edelstein, M. 2004. Grafting vegetablecrop plants: Pros and cons. Acta Hort. 659:235-238.

Fernández-Garcia, N., V. Martinez, and M. Carvajal. 2004. Fruit quality of grafted tomato plants grown under saline conditions. J. Hort. Sci. Biotechnol. 79:9951001 .

Flores, F.B., P. Sanchez-Bel, M.T. Estañ, M.M. Martinez-Rodriguez, E. Moyano, B. Morales, J.F. Campos, J.O. Garcia-Abellán, 
M.I. Egea, N. Fernández-Garcia, F. Romojaro, and M.C. Bolarín. 2010. The effectiveness of grafting to improve tomato fruit quality. Scientia Hort. 125:211-217.

Kader, A.A., M.A. Stevens, M. AlbrightHolton, L.L. Morris, and M. Algazi. 1977. Effect of fruit ripeness when picked on flavor and composition in fresh market tomatoes. J. Amer. Soc. Hort. Sci. 102: 724-731.

Khah, E.H., E. Kakava, A. Mavromatis, D. Chachalis, and C. Goulas. 2006. Effect of grafting on growth and yield of tomato (Lycopersicon esculentum Mill.) in greenhouse and open-field. J. Appl. Hort. 8:3-7.

King, S.R., A.R. Davis, X. Zhang, and K. Crosby. 2010. Genetics, breeding and selection of rootstocks for Solanaceae and Cucurbitaceae. Scientia Hort. 127:106111 .

Klee, H.J. 2010. Improving the flavor of fresh fruits: Genomics, biochemistry, and biotechnology. New Phytol. 187:44-56.

Klein, D., V. Gkisakis, A. Krumbein, I. Livieratos, and U. Köpke. 2010. Old and endangered tomato cultivars under organic greenhouse production: Effect of harvest time on flavor profile and consumer acceptance. Intl. J. Food Sci. Technol. 45:2250-2257.

Krumbein, A. and H. Auerswald. 1998. Characterization of aroma volatiles in tomatoes by sensory analyses. Nahrung 42:395-399.

Kubota, C., M.A. McClure, N. KokalisBurelle, M.G. Bausher, and E.N. Rosskopf. 2008. Vegetable grafting: History, use, and current technology status in North America. HortScience 43:1664-1669.

Lee, J.M., C. Kubota, S.J. Tsao, Z. Bie, P. Hoyos Echevarria, L. Morra, and M. Oda. 2010. Current status of vegetable grafting: Diffusion, grafting techniques, automation. Scientia Hort. 127:93-105.
López-Pérez, J.A., M. Le Strange, I. Kaloshian, and A.T. Ploeg. 2006. Differential response of $\mathrm{Mi}$ gene-resistant tomato rootstocks to root-knot nematodes (Meloidogyne incognita). Crop Protection 25:382-388.

Martínez-Ballesta, M., L. López-Pérez, M. Hernández, C. López-Berenguer, N. Fernández-García, and M. Carvajal. 2008. Agricultural practices for enhanced human health. Phytochem. Rev. 7:251260 .

Mattheis, J.P. and J.K. Fellman. 1999. Preharvest factors influencing flavor of fresh fruit and vegetables. Postharvest Biol. Technol. 15:227-232.

Mišković, A., Ž. Ilin, and V. Marković. 2009. Effect of different rootstock type on quality and yield of tomato fruits. Acta Hort. 807:619-624.

Olson, S.M., W.M. Stall, G.E. Vallad, S.E. Webb, S.A. Smith, E.H. Simonne, E.J. McAvoy, B.M. Santos, and M. OzoresHampton. 2011. Tomato production in Florida, p. 309-332. In: S.M. Olson and B.M. Santos (eds.). Vegetable production handbook for Florida. Vance Publishing, Lincolnshire, IL.

Pogonyi, Á., Z. Pék, L. Helyes, and A. Lugasi. 2005. Effect of grafting on the tomato's yield, quality and main fruit components in spring forcing. Acta Aliment. 34:453-462.

Raffo, A., C. Leonardi, V. Fogliano, P. Ambrosino, M. Salucci, L. Gennaro, R. Bugianesi, F. Giuffrida, and G. Quaglia. 2002. Nutritional value of cherry tomatoes (Lycopersicon esculentum Cv. Naomi F1) harvested at different ripening stages. J. Agr. Food Chem. 50:6550-6556.

Rivard, C.L. and F.J. Louws. 2008. Grafting to manage soilborne diseases in heirloom tomato production. HortScience 43:21042111.
Rivard, C.L., S. O’Connell, M.M. Peet, and F.J. Louws. 2010a. Grafting tomato with interspecific rootstock to manage diseases caused by Sclerotium rolfsii and southern root-knot nematode. Plant Dis. 94:1015-1021.

Rivard, C.L., O. Sydorovych, S. O'Connell, M.M. Peet, and F.J. Louws. 2010b. An economic analysis of two grafted tomato transplant production systems in the United States. HortTechnology 20: 794-803.

Romano, D. and A. Paratore. 2001. Effects of grafting on tomato and eggplant. Acta Hort. 559:149-153.

Rouphael, Y., D. Schwarz, A. Krumbein, and G. Colla. 2010. Impact of grafting on product quality of fruits and vegetables. Scientia Hort. 127:172-179.

Terada, M., Y. Watanabe, M. Kunitomo, and E. Hayashi. 1978. Differential rapid analysis of ascorbic acid 2-sulfate by dinitrophenylhydrazine method. Ann. Biochem. 84:604-608.

Turhan, A., N. Ozmen, M.S. Serbeci, and V. Senz. 2011. Effects of grafting on different rootstocks on tomato fruit yield and quality. Hort. Sci. (Prague) 38:142-149.

U.S. Department of Agriculture. 2002. Code of Federal Regulations, Title 7, Part 205. National Organic Program. 8 Aug. 2011. <http://www.ams.usda.gov/ AMSvl.0/getfile?dDocName=STELDEV $3004452>$.

Vinkovic Vrcek, I., V. Samobor, M. Bojic, M. Medic-Saric, M. Vukobratovic, R. Erhatic, D. Horvat, and Z. Matotan. 2011. The effect of grafting on the antioxidant properties of tomato (Solanum lycopersicum L.). Spanish J. Agr. Res. 9:844-851. 